\title{
Fundamental Study on Solvent Sublation Using Salphen and Its Application for Separative Determination of Trace Ni(II), $\mathrm{Co}(\mathrm{II})$ and $\mathrm{Cu}(\mathrm{II})$ in Water Samples
}

\author{
Young-Sang Kim, ${ }^{\star}$ Gyo In, ${ }^{\dagger}$ Mi-Hyun Kim, ${ }^{4}$ and Jong-Moon Choi ${ }^{\S}$ \\ Department of Chemistry, Korea University, Jochiwon, Choongnam 339-700, Korea. "E-mail. vskim41@korea.ac.kr \\ "KT\& G Central Research Institute, Daejeon 305-805, Korea \\ "Daejoo Electronic Materials Co., LTD., Sihwa Ind Estate 1Ra 110, Sihung 123-610, Korea \\ ${ }^{\S}$ Department of Environmental Engineering, Hanzhong University, Donghae 240-150, Korea \\ Received Jily 8, 2006
}

\begin{abstract}
$\Lambda$ solvent sublation using salphen as a ligand was studied and applied for the determination of trace Ni(II), Co(II) and $\mathrm{Cu}(\mathrm{II})$ in water samples. The fundamental study was investigated by a solvent extraction process because the solvent sublation was done by extracting the floated analytes into an organic solvent from the aqueous solution. The salphen complexes of $\mathrm{Ni}$ (II), $\mathrm{C}$ (II) and $\mathrm{Cu}$ (II) ions were formed in an alkaline solution of more than $\mathrm{pII} 8$ and then they were extracted into m-xylene. It was known that the each metallic ion formed $1: 1$ complex with the salphen and the logarithmic values of extraction constants for the complexes were 3.3 5.1 as an average value. Based on the preliminary study, the procedure was fixed for the separation and concentration of the analytes in samples. Various conditions such as the pII of solutions, the influence of $\mathrm{NaClO}_{4}$, the bubbling rate and time of $\mathrm{N}_{2}$ gas, and the type of organic solvent were optimized. The metalsalphen complexes could be extracted into m-xylene from the solution of more than $\mathrm{pII} 8$, but the $\mathrm{pII}$ could be shifted to acidic solution of $\mathrm{pII} 6$ by the addition of $\mathrm{NaClO}_{4}$. In addition, the solvent sublation efficiency of the analytes was increased by adding $\mathrm{NaClO}_{4}$. The recovery of $97-115 \%$ was obtained in the spiked samples in

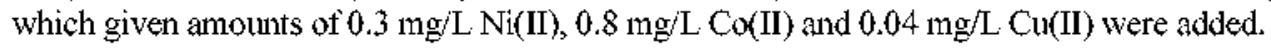

Key Words : Solvent sublation, Salphen, Nickel(II), Cobalt(II), Copper(II)

\section{Introduction}

Since Jacobsen and Katsuki used salen for the epoxy formation of olefin by the catalytic reaction as a homogeneous catalyst of the Mn(II)-salen compound, ${ }^{1,2}$ the salen has been widely used in various organic reactions as catalysts of metal-salen complexes because of their high selectivity to the reaction. It was a Schiff's base. Many kinds of salen complexes of transition elements and aluminum were synthesized by Hitherto. ${ }^{3}$ Wang et al. synthesized salen and salphen as forenunners of effective catalyst for the polymerization of oligomer compounds. ${ }^{4}$ And Kleij et al. used Zn(II)salen complex for the synthesis of high polymers. ${ }^{\text {. }}$

But there were not so many cases to use the salen and salphen as a chelating agent for the separation and determination of trace inorganic elements. Only two cases had been reported for the analytical uses until salen and its derivatives were used in this laboratory. At first, the salen was used as a Mn(II)-salen complex for the solvent extraction of Mn(II) from a sample solution. ${ }^{6}$ Trace Cu(II) was determined by a solid phase extraction with a salen derivative adsorbed on the surface of silica gel. ${ }^{7}$ Therefore some intensive studies have been performed on the analytical applications of salen and its derivatives in our laboratory.

As the first attempt, a solvent extraction with the salen complex was applied for the determination of trace amount of Ni(II) in sea water to evaluate the selectivity and reliability of this procedure in a complex matrix of the sample. ${ }^{8}$ The salen was synthesized for ourselves. And a solid phase extraction was studied for the determination of trace $\mathrm{Cu}(\mathrm{II})$, $\mathrm{Pb}$ (II) and $\mathrm{Bi}(\mathrm{III})$ by using a salen-XAD resin. ${ }^{9}$ The salen$\mathrm{XAD}$ resin was synthesized by the chemical bonding of the salen on the $\mathrm{XAD}$ resin. The extraction was done by a batch method and the elements adsorbed were dissolved in nitric acid solution containing Pd(III) to measure AAS absorbances. Followed the salen-XAD resin study, the salen( $\left(\mathrm{NEt}_{2}\right)_{2}$ was bound on the surface of silica gel $60^{\mathrm{TM}}$ (MERCK) by a diazonium coupling reaction to be applied for the determination of trace $\mathrm{Cu}(\mathrm{II}), \mathrm{Mn}$ (II), $\mathrm{Pb}$ (II) and $\mathrm{Zn}$ (II) by the solid phase extraction. ${ }^{10}$ The analytes were dissolved from the silica gel for the AAS measurement. In addition, five kinds of salen derivatives were synthesized to evaluate their applicability for the analytical purpose.

In this work, the use of salphen $\left\{N, N^{\prime}\right.$-Bis(salicylidene)phenylenediamine\} was investigated for the solvent sublation to separate and concentrate some trace elements for the determination. The salphen was another type of salen derivative. Unlike the ethylenediamine of salen, salphen included a phenylenediamine as a backbone. The salphen was synthesized and used to form metal-salphen complexes for the extraction of metal ions into a solvent.

The solvent sublation was a combined technique of a flotation and a solvent extraction. The salphen complexes were floated by bubbling gas and the floated complexes were extracted into a light solvent on the surface of original sample solution. ${ }^{11}$ The sublation had a good advantage to pre-concentrate analytes with a big ratio from large volume sample to a small volume of solvent. Besides, some 
necessary fundamental studies were done for the effective sublation of elements by the solvent extraction to optimize sublation conditions. And the recovery test was performed to evaluate the applicability to practical analysis of real samples.

\section{Experimental Section}

Reagents and instruments. Analytical grade of reagents were used without further purification and a deionized water was made by the purification of distilled water with MILLI$\mathrm{Q}^{\mathrm{TM}}$ water system of Millipore company. All solvents used were of HPLC grade. The salphen was dissolved in DMF.

The structure of the salphen synthesized was identified with $300 \mathrm{MHz}$ 'H NMR spectrometer of Varian OXFORD mecury 300. Atomic absorption spectrophotometer of PerkinElmer, Model 2380, was used to measure the absorbance of analytes.

Synthesis of salphen. After dissolving one mole of phenylenediamine (Baker, USA) in $150 \mathrm{~mL}$ of ethyl alcohol at room temperature, two mole of salicylaldehyde (Aldrich, USA) was added into the solution, stirring with a magnetic stirrer slowly. The yellow crystal of salphen was obtained 8 hours later and the crystal was purified by the re-crystallization of it in the cold solvent of ethyl alcohol and $n$-hexane. The salphen was identified by NMR spectrum as shown in Table 1 . The synthetic procedure was shown as Scheme 1.

Extraction constants of metal-salphens. After one liter of dejonized water was taken in an erlenmeyer flask, one mole of $\mathrm{NaCl}$ was added to control the sample matrix and the $\mathrm{pH}$ was adjusted to 8 with $\mathrm{KH}_{2} \mathrm{PO}_{4} / \mathrm{NaOH}$ buffer solution. A series of $25 \mathrm{~mL}$ solution were taken in separatory funnels and the $20 \mathrm{mg} / \mathrm{L}$ standard solutions of $\mathrm{Ni}$ (II), Co(II) and $\mathrm{Cu}(\mathrm{II})$ were added in each solution. The salphen solution in DMF was added to the separatory furnels, increasing the concentration. In this case, the salphen was a limiting reagent to form metal complexes. After $25 \mathrm{~mL}$ of $m$-xylene was added to each furnel, the furnels were shaken for 30 minutes with a mechanical shaker to partition the complex to

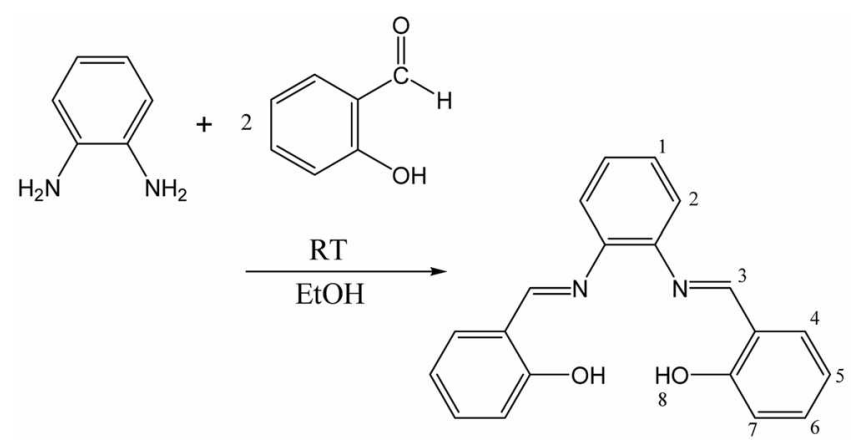

Scheme 1. The synthesis of salphen.

Table 1. 'H NMR spectrum of synthesized salphen in $\mathrm{CDCl}_{3}$ solvent

\begin{tabular}{rrrrrr}
\hline Peak & $\mathbf{1}\left(\mathrm{CH}_{2}\right)$ & $\mathbf{2 ( \mathrm { CH } _ { 2 } )}$ & $\mathbf{3}(\mathrm{CH})$ & $\mathbf{4 - 7}\left(\mathrm{CH}_{2}\right)$ & $\mathbf{8}(\mathrm{OH})$ \\
\hline & $\delta 6.890$ & $\delta 7.042$ & $\delta 8.643$ & $\delta 7.230$ & $\delta 11.019$ \\
6.914 & 7.069 & & -7.404 & \\
6.938 & & & & \\
\hline
\end{tabular}

the solvent. The extracted complexes were back-extracted into $25 \mathrm{~mL}$ of $3 \mathrm{~mol} / \mathrm{L}$ nitric acid solution to measure the absorbance of elements. From the concentration of the analytes measured in the nitric acid solution, the concentration of each element extracted was calculated as a concentration in the original aqueous solution. And the concentration remained in the original solution was obtained by subtracting the calculated value from the initially given concentration. Then, the distribution ratios, the extraction constants and the composition of complexes were calculated by using the corresponding equations.

Determination of elements by a solvent sublation. After $1.0 \mathrm{~L}$ of sample solution was taken in an erlenmeyer flask, a given amount of $\mathrm{NaCl}$ was added to this solution to control the solution matrix at $0.1 \mathrm{~mol} / \mathrm{L} \mathrm{NaCl}$. And $28 \mathrm{~mL}$ of 0.2 $\mathrm{mol} / \mathrm{L} \mathrm{NaClO}_{4}$ solution was added and the $\mathrm{pH}$ was adjusted at 8 by adding $\mathrm{KH}_{2} \mathrm{PO}_{4} / \mathrm{NaOH}$ buffer solution. $\mathrm{A} 30 \mathrm{~mL}$ of $0.2 \%$ salphen in DMF was added and the solution was stirred for 30 minutes. All solution was transferred into a flotation cell of $1 \mathrm{~L}$ and $20 \mathrm{~mL}$ of $m$-xylene was added on the surface of the solution. And nitrogen gas was bubbled for 20 minutes at the rate of $100 \mathrm{~mL} / \mathrm{min}$. A proper volume of the $m$-xylene solvent was taken by a pipette for the measurement of AAS absorbance. A series of standard solutions including several gradient concentrations of analytes were treated with the same procedure as the sample to make a calibration curve.

For the recovery test, given volume of analyte solutions were spiked to $1.000 \mathrm{~mL}$ sample solution to make the concentrations of $0.3,0.8$ and $0.04 \mathrm{mg} / \mathrm{L}$ for $\mathrm{Ni}(\mathrm{II}), \mathrm{Co}$ (II) and $\mathrm{Cu}(\mathrm{II})$, respectively. These solutions were also treated with the same procedure as sample.

\section{Results and Discussion}

Extraction constants of metal-salphen complexes. The extraction mechanism and extraction equilibrium constant was necessary to be examined for the metal-salphen complexes because the efficiency of solvent sublation was strongly influenced by the solvent extraction. And such basic studies might be helpful to understand the stoichiometry for the formation of metal complexes with the salphen.

On the other hand, the basic studies such as a mechanism, a mathematical treatment and so on have been performed for the solvent sublation. Valsaraj et al had studied the procedure of the solvent sublation in several papers. ${ }^{1112}$ The solvent sublation technique of a batch method was used to remove chlorinated pesticides from environmental aqueous samples in 1986. The procedure was examined to develop an efficient removal of the pesticides in the work. "I And the separation and determination of pentachlorophenol (PCP), one kind of environmental hormone, was done using the solvent sublation technique by them in $1991 .^{12}$ The PCP was bound with a surfactant of hexadecyltrimethylammonium bromide(HTMAB) in a basic range of $\mathrm{pH} 8-9$ to form a neutral compound. The bond was dependent on the ionic character of PCP. Besides, Yujuan et al. looked into mathe- 
matical mechanism minutely for the solvent sublation of some materials by using surfactants of cetylpyridinium chloride (CPC) and dodecylbenzenesulfonic (LDBS) acid. ${ }^{13}$ In this study, a synergistic effect was shown on the sublation of environmental materials by the use of the surfactants.

In this work, the solvent sublation was utilized to concentrate trace amount of ion in a small volume of solvent from the large volume sample solution. For this sublation, we can derive some equations from the extraction mechanism of metal-salphen complexes. ${ }^{1+}$ The procedure was done to be applied in other case of sublation in this laboratory.

At first, the salphen was dissociated in a basic solution as following:

$$
\mathrm{H}_{2} \text { salphen }=2 \mathrm{H}^{\prime}+\text { salphen }^{2-}
$$

The dissociated salphen ${ }^{2-}$ ion formed a complex with divalent metal ions.

$$
\mathrm{aM}^{2 \mathrm{H}}+\mathrm{b}\left(\text { salphen }^{2-}\right)=\mathrm{c}(\mathrm{M}-\text { salphen })
$$

The metal-complex could be extracted into $m$-xylene.

$$
\mathrm{c}(\mathrm{M}-\mathrm{s} \text { alphen })=\mathrm{c}(\mathrm{M}-\mathrm{salphen})_{\mathrm{cro}}
$$

Therefore, the total equation could be expressed as a chemical equation (4).

$$
\mathrm{aM}^{2+}+\mathrm{b}\left(\text { salphen }^{2-}\right)=\mathrm{c}(\mathrm{M}-\text { salphen })_{\text {oro }}
$$

In these equations, the subscript of $a q$ which meant an aqueous solution was not used. The subscript org was an organic layer. In order to obtain stoichiometric values of $a, b$ and $c$ in the equations, the complexes were extracted at the constant concentration of metal ions by increasing the concentration of salphen under given conditions. The concentrations of metal ions extracted were calculated from the AAS absorbance data. The extracted metallic concentration was increased with the increase of salphen with a nomal proportionality. That is, the slope was nearly 1 . The slope of 1 meant $1: 1$ complexes of metal ions and salphen. Therefore, the equation (4) could be expressed as equation (5).

$$
\mathrm{M}^{2+}+\text { salphen }^{2-}=(\mathrm{M}-\mathrm{salphen})_{\text {org }}
$$

The extraction constant $\left(K_{\mathrm{ex}}\right)$ of metal-salphen was calculated with an equation (6). The distribution coefficient $(D)$ was the ratio of the total concentration of extracted metal ion as a salphen complex to the total concentration of remained metal ion.

$$
\mathrm{K}_{\mathrm{ex}}=\frac{\left[\mathrm{M}-\text { salphen }_{\text {ort }}\right.}{\left[\mathrm{M}^{2-}\right] \cdot\left[\text { salphen }^{2-}\right]}=\frac{\mathrm{D}}{\left[\text { salphen }^{2-}\right]}
$$

In this equation, D was given as an equation (7).

$$
\mathrm{D}=\frac{[\mathrm{M}-\mathrm{salphen}]_{\mathrm{ors}}}{\left[\mathrm{M}^{2-}\right]}
$$

The logarithmic value $\left(\log K_{\text {ex }}\right)$ of the extraction constants was 3.27-5.07 as shown in Table 2. From these large values, it could be known that three kinds of analytes were quantitatively sublated into $m$-xylene from the aqueous sample.

Effect of pH on solvent sublation efficiency. A stable complex of metal-salphen should be formed for the effective solvent sublation of it. But the formation of the complex was strongly influenced by solution $\mathrm{pH}$ because the salphen was a weak dibasic acid as shown above. Conclusively the sublation of metal-salphen was significantly dependent upon the $\mathrm{pH}$.

Therefore, the extraction efficiency of salphen complexes of $\mathrm{Ni}(\mathrm{II}), \mathrm{Co}(\mathrm{II})$ and $\mathrm{Cu}(\mathrm{II})$ was investigated by the solvent sublation technique changing the $\mathrm{pH}$ of aqueous solution from 4 to 10 . The buffer solution was added to $1 \mathrm{~L}$ of the aqueous solution to control the solution $\mathrm{pH}$. Three kinds of ions were presented at the concentration of $20 \mathrm{mg} / \mathrm{L}$. And these solutions were treated with the given procedure in experimental section. The absorbances of metals extracted in $20 \mathrm{~mL}$ of $m$-xylene were measured by flame AAS.

As shown in Figure 1, the maximum plateau of the absorbance for three elements appeared in the basic solution of more than $\mathrm{pH} 8$. The phenomena could be explained with fact that $-\mathrm{OH}$ functional groups in the salicylaldehyde binding on both side of imine was easily dissociated to $-\mathrm{O}^{-}$ in such basic solution to form the coordination bond with metal ions. ${ }^{12}$ The coordination bond could occur by the large ability of electron pair donation to metal ions. ${ }^{15}$

Flotation ability according to the type of surfactant. In general, a surfactant can help the flotation of some precipitates or complex ions by making their surface or interface hydrophobic from hydrophilic property to be partitioned into an organic solvent from the aqueous solution. ${ }^{16}$ That is, the

\begin{tabular}{|c|c|c|c|c|c|c|c|c|}
\hline & [salphen] & $\log \mathrm{K}_{\mathrm{cx}}$ & & [salphen] & $\log \mathrm{K}_{\mathrm{ck}}$ & & [salphen] & $\log \mathrm{K}_{\mathrm{xx}}$ \\
\hline \multirow[t]{8}{*}{$\mathrm{Ni(II)}$} & $1.9 \times 10^{-5}$ & 3.65 & \multirow[t]{8}{*}{$\mathrm{Co}(\mathrm{II})$} & $1.17 \times 10^{-5}$ & 3.86 & \multirow[t]{8}{*}{$\mathrm{Cu}(\mathrm{II})$} & $4.33 \times 10^{-6}$ & 5.49 \\
\hline & $4.09 \times 10^{-5}$ & 3.37 & & $2.11 \times 10^{-5}$ & 3.75 & & $8.21 \times 10^{-6}$ & 5.36 \\
\hline & $5.55 \times 10^{-5}$ & 3.28 & & $2.52 \times 10^{-5}$ & 3.65 & & $1.17 \times 10^{-5}$ & 5.23 \\
\hline & $6.85 \times 10^{-5}$ & 3.21 & & $3.19 \times 10^{-5}$ & 3.58 & & $1.43 \times 10^{-5}$ & 4.97 \\
\hline & $8.96 \times 10^{-5}$ & 3.16 & & $3.66 \times 10^{-5}$ & 3.51 & & $1.73 \times 10^{-5}$ & 4.89 \\
\hline & $1.02 \times 10^{-4}$ & 3.11 & & $4.12 \times 10^{-5}$ & 3.46 & & $2.01 \times 10^{-5}$ & 4.83 \\
\hline & \multirow[t]{2}{*}{$1.22 \times 10^{-4}$} & 3.07 & & $4.73 \times 10^{-5}$ & 3.41 & & $2.15 \times 10^{-5}$ & 4.73 \\
\hline & & & & $5.46 \times 10^{-5}$ & 3.37 & & & \\
\hline
\end{tabular}
materials make a bond with the hydrophilic site of the surfactant in order to be hydrophobic. Therefore the hydrophobic materials are easily separated from an aqueous solution to be floated on the surface by a gas bubbling. And the surfactants are divided to three kinds of cationic, anionic

Table 2. Solvent extraction data and extraction constants at equilibrium 


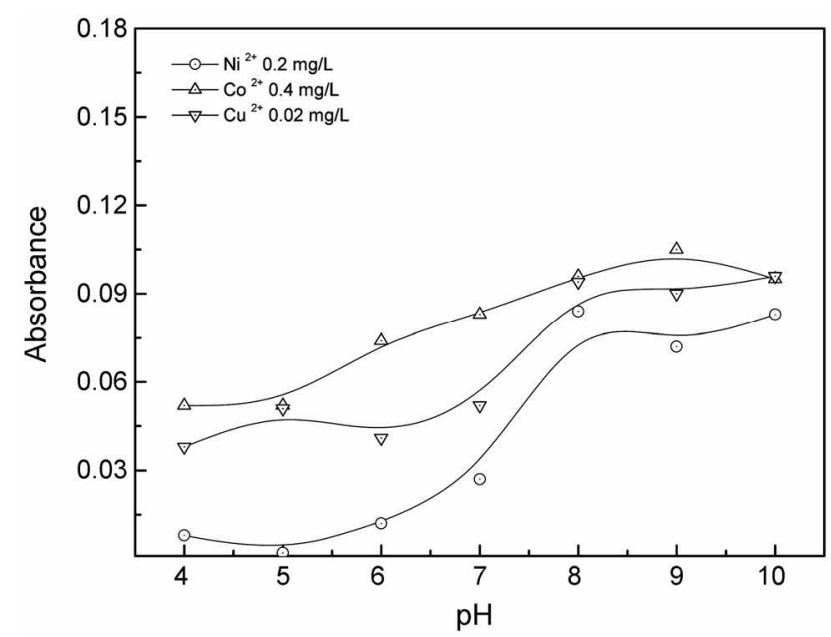

Figure 1. Effect of $\mathrm{pH}$ on solvent sublation of metal-salphen complexes into $m$-xylene.

and neutral ones. The complexes can be associated with the surfactant depending on the polarity of them to make a neutral or weak polar materials. ${ }^{17}$

In this work, the effect of surfactants on the sublation efficiency of metal-salphen complexes was investigated by using cetyltrimethylammonium bromide (CTAB) and cetylpyridine chloride (CPC) as cationic ones, sodium laury] sulphate (SLS) as a anionic, and Triton $\mathrm{X}-100$ as a neutral (Fig. 2). Unexpectedly, the low sublation efficiency was obtained for most of analytes compared to the case without the surfactant. The reason of low efficiency could be considered that there was the formation of neutral metal-salphen complexes as well as the insolubility of surfactants in $m$ xylene. But even the cause could not be explained, only copper-salphen complex under the addition of triton-X 100 showed much higher efficiency than other ions. Therefore any surfactants were not used because all of the complexes should be simultaneously sublated.

Function of auxiliary reagents for the synergistic sublation. In order to enhance the extraction efficiency of metal complexes, some synergistic function has been utilized by using a proper reagent. ${ }^{18,19}$ It was known that there were

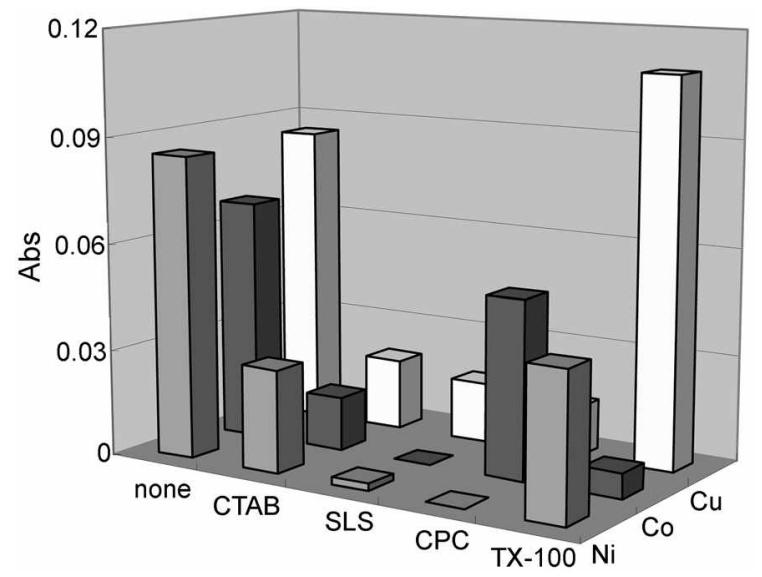

Figure 2. Effects of various surfactants on solvent sublation of analytes with $m$-xylene under other optimum conditions. many kinds of auxiliary reagents for a solvent extraction. In this work, three kinds of salts such as $\mathrm{NaClO}_{4}, \mathrm{KSCN}$ and tetrabutylammonium bromide (TBABr) were used to enhance the sublation efficiency of metal-salphen complexes. As shown in Figure 3, the addition of $\mathrm{NaClO}_{4}$ provided the best efficiency for all analytes.

Such good efficiency could be explained with salting-out effect by the addition of $\mathrm{NaClO}_{4}$. The $\mathrm{NaClO}_{4}$ has a very strong ionic property compared to other two salts so that the anti electric constant can be decreased in an aqueous solution. In this case, $0.1 \mathrm{~mol} / \mathrm{L}$ of $\mathrm{NaCl}$ was added to water samples for the purpose of adjustment of ionic strength so that its salting-out effect was not enough to decrease the anti electric constant. The constant was inversely proportional to the stability constant of complexes. ${ }^{20}$ Therefore, $\mathrm{NaClO}_{4}$ was selected as an auxiliary reagent.

And the concentration of $\mathrm{NaClO}_{4}$ was optimized to obtain the good effect in this solvent sublation. The extraction efficiency of the complexes was investigated by changing the concentration of the $\mathrm{NaClO}_{4}$ which was varied up to 0.4 $\mathrm{mol} / \mathrm{L}$. A maximum plateau of the extraction was obtained at the higher concentration than $0.2 \mathrm{~mol} / \mathrm{L} \mathrm{NaClO}_{4}$ solution for three elements. But the addition of much high concentration decreased the extraction efficiency because other kinds of the floated materials interfered with the flotation of metalsalphen complexes for their sublation. Therefore $0.2 \mathrm{~mol} / \mathrm{L}$ of $\mathrm{NaClO}_{4}$ was used in the sample solution. Sometimes the absorbance of the elements extracted tended to be increased somewhat by the addition of $\mathrm{NaClO}_{4}$ in the case of $\mathrm{Co}$ (II) and $\mathrm{Cu}$ (II).

And the range of optimum $\mathrm{pH}$ was also shifted to an acidic range by the addition of $\mathrm{NaClO}_{4}$ as shown in Figure 4 . That is, the maximum plateau of the absorbance was started from $\mathrm{pH}$ 6. This change could be explained by this fact that $\mathrm{NaClO}_{4}$ could suppress the dissociation of salphen to phenylenediamine and salicylaldehyde even in a weak acidic solution. And compared to salen, it could be known that the selectivity and stability of metal complexes were increased in a weak acidic range because of the presence of phenyl group in salphen.

Sublation ability depending upon the type of solvent. There are several limits in the selection of solvent for a

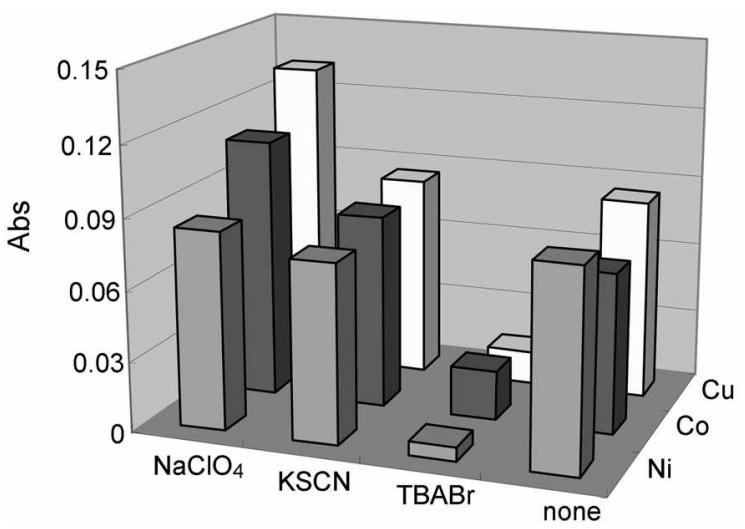

Figure 3. Extraction efficiency of metal-salphen complexes according to the type of salt. 


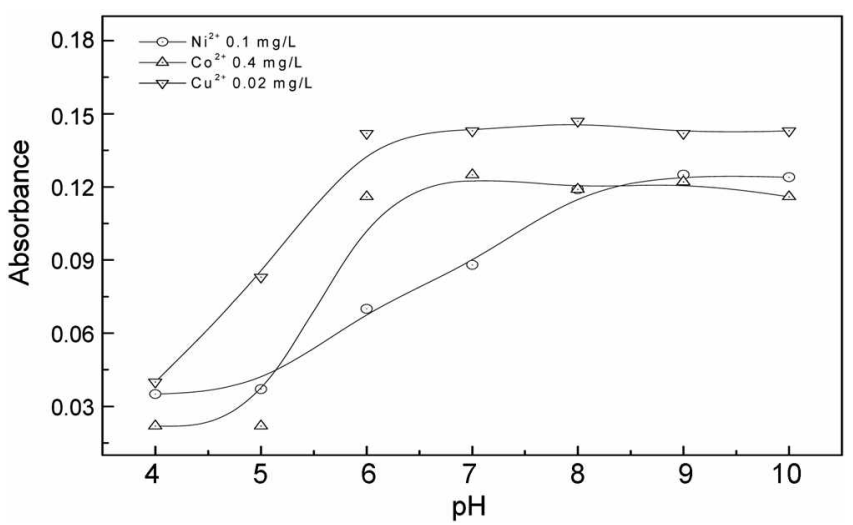

Figure 4. The effect of $\mathrm{pH}$ on solvent sublation of metal-salphen complexes into $m$-xylene in presence of $\mathrm{NaClO}_{4}$.

solvent sublation. ${ }^{20.21}$ The solvent must have a good affinity to the complexes for the efficient partition of them to a solvent and has to be lighter than an aqueous solution because the complexes have to be floated upward by a gas bubbling. And it should have a low volatility to prevent the big variation of the volume for the bubbling duration. In addition, the solvent should not provide a significant background in the absorbance measurement of flame-AAS.

Several solvents such as $m$-xylene, methyl isobutyl ketone (MIBK) and $n$-hexane were studied for the effective sublation of metal-salphen complexes. These solvent were water immiscible and lighter than water. As shown Figure 5, $\mathrm{Ni}(\mathrm{II})$-salphen was efficiently extracted into $n$-hexane and Co(II) complex was extracted into MIBK well. But $m$ xylene was used as a solvent in this case because it could sublate three kinds of analyte ions simultaneously. Such effective extraction was explained with a structural similarity by the presence of aromatic ring between salphen and $m$-xylene. The Ni(II)-salphen complex extracted into $m$ xylene could be confirmed by the appearance of its own color of reddish brown in the solvent.

Bubbling velocity and time of nitrogen gas. As described previously, the solvent sublation was a combined method of flotation and solvent extraction. Firstly, a proper form of metal-salphen complex should be floated from a bulk solution to the surface of the solution and the complex was extracted into a solvent. The flotation was a very important step for the sublation of the complex. A nitrogen gas was

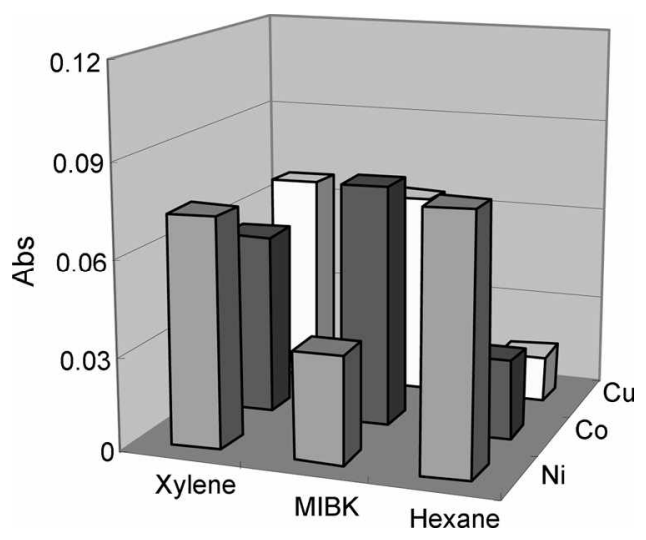

Figure 5. The effect of organic solvent type on the sublation efficiencies of analytes under given optimum conditions.

widely and frequently bubbled to float the complexes because the gas was inert and cost-effective.

And the size of the bubbles was so small that the interface between the gas and solution should be large for the effective flotation. The bubbling rate must to be adjusted to obtain a proper size of the bubbles and the bubbling time was also important to float and keep the complexes on the surface. ${ }^{22}$ In this experiment, the highest sublation efficiency could be obtained for three elements by bubbling of the $\mathrm{N}_{2}$ gas for 20 minutes at the rate of $100 \mathrm{~mL} / \mathrm{min}$. If the bubbling time were much longer, the bubble size increased and the floated complexes were redistributed into the bulk solution, resulting in low sublation efficiency. ${ }^{23}$

Interference of concomitant ions in the analysis of real samples. Usually there are kinds of elements in water samples, especially at high content in sea water. Such concomitant ions can interfere with the solvent sublation of these three kinds of trace elements. ${ }^{15}$ In some case, the concomitant ions can interfere with the salphen complex formation of analyte ions by the formation of their more stable complexes, as a result, their complexes can be co-extracted with analyte complexes so that much more ligand such as salphen is necessary for the complete extraction of analytes.

In this work, the interferences of concomitant ions were investigated by adding the ions to the solution of given concentration of $\mathrm{Ni}$ (II), $\mathrm{Co}$ (II) and $\mathrm{Cu}$ (II) up to twice of their average concentration in sea water. As shown Table 3, the absorbance of three analyte elements extracted were

Table 3. Concentration of the major and minor ions in sea water and their tolerance limits

\begin{tabular}{|c|c|c|c|c|c|}
\hline \multirow{2}{*}{ Elements } & \multirow{2}{*}{$\begin{array}{l}\text { Concentration in sea water }{ }^{*} \\
\qquad(\mathrm{mg} / \mathrm{L})\end{array}$} & \multicolumn{3}{|c|}{ Tolerance limit (mg/L) } & \multirow{2}{*}{$\begin{array}{c}\text { Some probable dissolved } \\
\text { species }\end{array}$} \\
\hline & & $\mathrm{Ni}$ (II) & $\mathrm{Co}(\mathrm{II})$ & $\mathrm{Cu}(\mathrm{II})$ & \\
\hline Sodium & $1.08 \cdot 10^{4}$ & - & - & - & $\mathrm{Na}^{-}$ \\
\hline Potassium & $3.80 \cdot 10^{2}$ & - & - & - & $\mathrm{K}^{-}$ \\
\hline Magnesium & $1.29 \cdot 10^{3}$ & - & - & - & $\mathrm{Mg}^{2-}$ \\
\hline Iron & $2 \times 10^{3}$ & - & - & - & $\mathrm{Fe}(\mathrm{OH})^{-}$ \\
\hline Chromium & $3 \times 10^{-4}$ & - & - & - & $\mathrm{Cr}(\mathrm{OH}):$ \\
\hline Zinc & $5.0 \times 10^{-4}$ & 0.5 & 1.0 & 0.5 & $\mathrm{ZnOH}$ \\
\hline Manganese & $2.0=10^{-4}$ & 1.0 & 0.5 & 0.5 & $\mathrm{Mn}^{2} \cdot$ \\
\hline Calcium & $4.12 \times 10^{2}$ & $4.0 \times 10^{3}$ & $4.0 \times 10^{3}$ & $4.0 \times 10^{3}$ & $\mathrm{Ca}^{2}$ \\
\hline
\end{tabular}

"Douglas A. Segar, "Introdkction to OCEAN SCIENCES", Wadsworth, Belmont, USA, 1998. 
Table 4. Analytical results and recoveries of the three elements in water samples

\begin{tabular}{|c|c|c|c|c|c|c|c|c|c|}
\hline \multirow[b]{2}{*}{ Sample } & \multicolumn{3}{|c|}{$\mathrm{Ni}(\mathrm{II})$} & \multicolumn{3}{|c|}{$\mathrm{Co}(\mathrm{II})$} & \multicolumn{3}{|c|}{$\mathrm{Cu}(\mathrm{II})$} \\
\hline & $\begin{array}{l}\text { Added } \\
(\mathrm{mg} / \mathrm{L})\end{array}$ & $\begin{array}{l}\text { Found } \\
(\mathrm{mg} / \mathrm{L})\end{array}$ & $\begin{array}{c}\text { Recovered } \\
(\%)\end{array}$ & $\begin{array}{l}\text { Added } \\
(\mathrm{mg} / \mathrm{L})\end{array}$ & $\begin{array}{l}\text { Found } \\
\text { (mg/L) }\end{array}$ & $\begin{array}{c}\text { Recovered } \\
(\%)\end{array}$ & $\begin{array}{l}\text { Added } \\
(\mathrm{mg} / \mathrm{L})\end{array}$ & $\begin{array}{l}\text { Found } \\
(\mathrm{mg} / \mathrm{L})\end{array}$ & $\begin{array}{c}\text { Recovered } \\
(\%)\end{array}$ \\
\hline \multirow[t]{2}{*}{ Tap-Water } & 0 & - & & 0 & - & & 0 & 0.009 & \\
\hline & 0.300 & 0.307 & $101.7 \%$ & 0.800 & 0.787 & $98.32 \%$ & 0.040 & 0.056 & $115.5 \%$ \\
\hline \multirow[t]{2}{*}{ Sea-Water } & 0 & - & & 0 & - & & 0 & - & \\
\hline & 0.300 & 0.294 & $97.9 \%$ & 0.800 & 0.772 & $96.6 \%$ & 0.040 & 0.046 & $114.5 \%$ \\
\hline
\end{tabular}

Number of analysis, $n=5,{ }^{*}-$ Not detected

decreased at the coexistence of more than $0.5 \mathrm{mg} / \mathrm{L} \mathrm{Zn(II)}$ and $\mathrm{Mn}(\mathrm{II})$ and more than $4.0 \times 10^{3} \mathrm{mg} / \mathrm{L} \mathrm{Ca}(\mathrm{II})$ in the solution. But the interferences of $\mathrm{Zn}(\mathrm{II}), \mathrm{Mn}(\mathrm{II}), \mathrm{Ca}(\mathrm{II})$ and other ions could be ignored in this experiment because their concentration was less than the tolerance limits.

Application of given procedure to real sample analysis. The sublation procedure optimized previously was applied to real samples of laboratory tap water and sea water to evaluate the applicability. Two kinds of water samples were filtered to remove the floated insoluble materials and $10 \mathrm{~mL}$ of concentrated nitric acid was added to $10 \mathrm{~L}$ samples to prevent the coagulation of some materials. After $1.0 \mathrm{~L}$ of each sample was taken in an Erlenmeyer flask, the sample was processed with the optimized procedure.

Besides, two kinds of standard solutions were prepared by adding a series of concentrations of the analytes into a deionized water for the analysis of tap water and into the synthesized sea water for sea water analysis. And the standard solutions were treated with the same procedure as samples.

Calibration curves plotted were linear at $R^{2}$ values of more than 0.99 . Only copper was detected in the tap water and other elements were not detected in both of water samples as shown Table 4. The copper was able to be detected with an excellent sensitivity by flame AAS compared to other two elements.

A recovery test was performed to evaluate the reliability of given method here. The analytes were added to $1.0 \mathrm{~L}$ of real samples to be $0.3,0.8$ and $0.04 \mathrm{mg} / \mathrm{L}$ for nickel, cobalt and copper respectively and the spiked samples were analysed by given solvent sublation procedure. The recoveries of $97-115 \%$ were obtained. From the favorable recoveries, the given method could be known to obtain the reliable analytical results in such samples.

\section{Conclusion}

The salphen could be used as an organic chelating agent to form stable metal-complexes for the determination of trace $\mathrm{Ni}(\mathrm{II}), \mathrm{Co}$ (II) and $\mathrm{Cu}(\mathrm{II})$ in water samples by a solvent sublation technique. The complexes were fonned in weak basic solution, but the $\mathrm{pH}$ range could be shifted to more acidic from $\mathrm{pH} 8$ to 6 by the addition of proper concentration of $\mathrm{NaClO}_{4}$. The salphen could form $1: 1$ complexes with these ions and the complexes were relatively stable with a large stability constant of $\log K$ between 3.27 and 5.07. The metalsalphen complexes could be solvent-sublated without any surfactants and the sublation efficiency could be increased by adding $\mathrm{NaClO}_{4}$. The floated complexes were extracted into $m$-xylene on the surface. It was confinned that the concomitant elements in real samples didn't interfere with the sublation up to twice of their average concentrations in sea water. And the recovery of $97-115 \%$ obtained from the spiked samples could make the proposed method reliable for the analysis of these kinds of samples.

\section{References}

I. Jacobsen, E. N.; Zhang, W; Guler, M. L. J. Am. Chem. Soc. 1991, IIS, 6703 .

2. Jacobsen, E. N.; Zhang, W.; Muci, M. L.; Ecker, J. R.; Deng, L. J. Ant. Chent. Soc 1991, H3, 7063 .

3. Leung, W. H.; Chan, E. Y. Y.; Chow, E. K. F,; Williams, I. D.; Peng, S. M. J. Chem. Soc. 1996, 1229.

4. Wang, M.; Zhu, H.; Huang, D.; Jin, K.; Chen, C.; Sun, L. J. Organomet. Chem. 2004, 689, 1217.

5. Kleii. A. W.; Kuil, M.; Lutz, M.; Tookd, D. M.; Spek, A. L.; Kamer, P. C. J.; Leeiwen, P. W. N. M.; Reek, J. N. H. Inor Chin. Acta 2006, 359, 1807.

6. Tantaru, G; Domeanu, V; Stan, M. J. Pharm. Biomed. Anal. 2002, 27,827

7. Shamsipur, M.; Ghiasvand, A. R.; Sharghi, H.; Naeimi, H. Andt. Chim Acta 2000, 408,27I.

8. In, G.; Choi, J. M.; Kim, Y. S. Antahtical Science \& Technology $2004,17(6), 481$.

9. Kim, Y. S.; In, G.; Han, C. W.; Choi, J. M. Mcrochem. J. 2005, 80,151 .

10. Kim, Y. S.; In, G.; Kim, E. J.; Kim, M. H.; Choi, J. M. Bull. Korean Chem. Soc. 2006, 26, Accepted.

I1. Kim. Y. S.; June, Y. J.; Choi, H. S. Bull. Korean Chem. Soc. 1998. 19,50 .

12. Valsaraj, K. T.; Porter, J. L.; Liljenfeldt, D. K. Wat. Res. 1986, 20, 1161.

13. Valsaraj, K. T.; Thibodeaus, L. J. Separation Science \& Technolog; $1991,26(1), 37$

14. Lu, Y. J.; Zhu, X. H. Tatanta 2002, 57, 891.

15. In, G, Ph.D. Dessertation, Korea University: 2004.

16. Lloret, F.; Mollar, M.; Faus, J.; Julve, M.; Castro, I, Lhorg. Chim. Acta 1991, $189,195$.

17. Kim, D. H.; Chang, S. K.; Park, S. W. Antal. Sci. \& Tech. 2000, 13, $27 \mathrm{~A}$.

18. Akatsuka, K.; Nobuyama, N.; Atsuya, I. Antal. Sci. 1998, 4, $28 \mathrm{I}$.

19. Kim, Y. S.; In, G. Chio, J. M. Bull. Korean Chem. Soc. 2000, 21, 855.

20. Kim, Y. S.; In, G; Chio, J. M. Bull. Korean Chem. Soc. 2003, 24, 1495.

21. Anderson, R. Sample Pretreatment and Separation; Chapman, N. B., Ed.; Wiley: New York, U. K., 1987; p 305.

22. Kim, Y. S.; Shin, J. H.; Choi, Y, S.; Lee, W; Lee, Y. I. Microchemical Joumal 2001, 68,99.

23. Lu, Y. J.; Liu, J. H.; Tang, J.; Wei, B.; Zhang, X. L. J. Colloid Interface Sci. 2005, 283, 278. 